\title{
CONSUMERS' ACCEPTABILITY OF LOCAL RICE BRANDS IN NIGERIA. WHICH MARKETING FUNCTIONS REALLY MATTER?
}

\author{
Uchenna Obih $^{1 \bowtie}$, Lloyd Baiyegunhi ${ }^{1}$ \\ ${ }^{1}$ School of Agricultural, Earth and Environmental Sciences, University of KwaZulu-Natal, South Africa
}

\begin{abstract}
With an average annual import bill of USD 300 million, Nigeria is the Africa's largest rice consuming and importing country. This has been attributed to the poor quality of locally produced rice. Despite huge investments of over USD 1.65 billion made by government and private sectors in rice processing over the last six years - which has led to dramatic improvements in the quality of local rice brands the consumers' preference for imported rice brands persists. Prioritizing the implementation of consumer demand-focused domestic marketing policies and programs could encourage the consumers' acceptability of local rice brands. Therefore, this study attempts to provide some insight, from the consumer perspective, on the local rice marketing managers' need to improve their functions. A binary logistic model was estimated using a 2014 dataset collected from a survey with 460 rice consumer households in the Federal Capital Territory (FCT) of Nigeria. The results showed empirical evidence for the consumers' acceptability of local rice brands in Nigeria and the need for improvements in marketing functions that enhance the promotion and distribution of local rice brands. The implications of these findings for the development of Nigeria's rice marketing policy are discussed.
\end{abstract}

Keywords: consumer's acceptability, local rice brands, marketing functions, Nigeria

\section{INTRODUCTION}

Rice (Oryza specie) is the most widely accepted and consumed staple food by both the urban and rural populace in Nigeria (Johnson et al., 2013), as $82 \%$ of Nigerians eat rice at least once a day (Ogundele, 2014). In Nigeria, before 2010 , about $71 \%$ of rice was processed by small-scale cottage mills with a capacity of $10-300 \mathrm{~kg} /$ hour. Most of them (usually located in major paddy rice areas of Lafia, Ekiti, Niger, Taraba, Ebonyi, Benue, and Kaduna) relied on obsolete processing equipment and lacked modern milling accessories such as de-stoners, polishers and color sorters (Lancon et al., 2003; PROPCOM, 2007). Consequently, the locally produced rice was of poor quality due to presence of stones, husk, impurities, large quantities of uneven and broken grains, etc. (Campbell et al., 2009). The local rice marketing system was characterized by many challenges such as low product specialization, high degree of price differentiation, poor packaging, grading and standardization (Ogundele, 2013). All these factors led to consumer preference for imported rice brands. Rice importation in Nigeria, which has been rising since the last two decades, is a drain on the country's foreign exchange reserves as Nigeria spends an average of USD 300 million per year to import rice (Johnson et al., 2013). As a panacea to huge import bills, studies have recommended some improvements to the quality of local rice brands

\footnotetext{
${ }^{\mathrm{BSc}}$ MSc Uchenna Obih, School of Agricultural, Earth \& Environmental Sciences, Discipline of Agricultural Economics, University of KwaZulu-Natal, P/Bag X01 Scottsville, Pietermaritzburg 3209, South Africa, e-mail: obih_uchenna@yahoo.com, https://orcid.org/0000-0002-6564-2173
} 
to compete favorably with imported brands (Gyimah-Brempong et al., 2012; Ogundele, 2014; PROPCOM, 2007; Tomlins et al., 2005).

In the last six years, the Nigerian government adopted an import substitution strategy, and huge investments were made by both government and private sectors in rice production and processing. The government's implementation of the Commercial Agricultural Credit Support Scheme (CACS) provided cheap intervention funds that encouraged and attracted private sector participation in the development of the rice sector. A report by CARD (2015) indicates that about USD 1.67 billion has been invested in the establishment of medium- to large-scale integrated rice processing mills in Nigeria since 2010. Today, more arable lands have been opened for rice farming; improved seeds have been developed, disseminated and adopted by farmers; and more than 35 modern rice mills have been established across the country, leading to increased rice output with an annual growth rate of more than $5 \%$ (Seck et al., 2010) and improved availability of high-quality local rice brands ${ }^{1}$ in Nigerian markets (CARD, 2015). Despite these improvements in output and quality of local rice brands, available literature shows that consumers generally prefer imported rice brands (Adeyeye et al., 2010; Campbell et al., 2009; Erenstein et al., 2003). This tends to suggest that the reason behind the consumers' preference for imported rice could be more of a persistent habitual perception rather than physiochemical superiority of imported rice over the local rice (Akaeze, 2010), and this perception has continued till this day.

Recent studies have recommended prioritizing the implementation of marketing policies and programs arising from consumer demand-focused research as a strategy for the development of Nigerian industry (Bamidele et al., 2010; Ogundele, 2014; USAID, 2009). Designing such policies and programs at micro and macro levels requires that policy makers have insights on the consumers' view of the functions of local rice marketers. There is evidence in literature supporting the

${ }^{1}$ In Nigeria, rice brands are generally categorized into two (local and imported) rice brands. However, local rice brands are further categorized into two major groups, depending on whether rice is produced by cottage or medium/large scale businesses. This study focuses on and refers to the local rice brands produced by medium/large-scale rice processing businesses where there have been substantial public and private investments in recent times. role of marketers' functions in influencing the consumer's acceptability of food products (Kotler and Keller, 2013; Nundkumar and Singh, 2016). However, information on the functions of local rice millers and marketers seen from the consumers' perspective appears scanty as little research has been done on this subject in Nigeria. Some studies which have attempted to provide some insights on rice marketing functions in Nigeria, have only done so from the millers' and marketers' perspective (PROPCOM, 2007; Bashorun, 2009). To the authors' best knowledge, there is no empirical evidence, from the consumers' perspective, of the effect of marketing functions on the consumers' acceptability of local rice brands. This study has therefore become imperative in view of the fact that the success of marketing managers depends on the understanding of factors affecting consumer pre-purchase needs and reconciling them with the interest of marketing companies (Jairo, 2008). Consumers are one of the main drivers of marketing strategies because they can respond to the company's action either positively, by purchasing its products, or negatively, by boycotting its products (Porter and Kramer, 2006). This study will shed some light on the areas where marketing managers of local rice brands need to improve their functions to adequately complement and consolidate the private and public sectors' huge investments in production and processing for a sustainable development of Nigeria's rice industry. Specifically, this study seeks to:

- determine the consumers' acceptability of local rice brands in Nigeria;

- identify, from the consumers' perspective, the marketing functions that significantly influence the consumer's acceptability of local rice brands

\section{THEORETICAL AND CONCEPTUAL FRAMEWORK}

According to McCarthy (1964), marketing mix is a combination of all the factors which a marketing manager can use to satisfy the target market. These are generally grouped into four categories, otherwise known as the 4Ps of marketing functions. Studies have shown that two of the 4Ps (pricing and product) are considered more important than the other two - place (physical distribution) and promotion (Kellerman et al., 1995; Kurtz and Boone, 1987; McDaniel and Hise, 1984). The theory of a firm's choice of marketing program is based on the marketing mix model (MMM) and its associated 
Obih, U., Baiyegunhi, L. (2018). Consumers' acceptability of local rice brands in Nigeria. Which marketing functions really matter? J. Agribus. Rural Dev., 2(48), 183-196. http://dx.doi.org/10.17306/J.JARD.2018.00412

switching of marketing functions to optimize or satisfy a profit function (Grönroos, 1994; Palmer, 2004). Marketing mix models (MMM) are econometric models developed to explain the response of sales or market share to expenditures on marketing functions variables (Tellis, 1988). The choice of an optimal marketing mix is one of the greatest challenges facing marketing managers. The number of possible strategies of the marketing mix has been pointed out to be infinite, and it is not yet clear which criteria a firm should rely on in choosing an optimum marketing mix (McCarthy, 1964). Therefore, since different marketing programs exert different degrees of influence on consumers (Kurtz and Boone, 1987; Kellerman et al., 1995), it becomes imperative for marketing managers to prioritize relevant investments in these marketing programs (Martensen and Mouritsen, 2016).

MMM models follow a top-down approach and are used by marketing managers to measure productivity and returns, and for optimizing expenditures on marketing functions based on sales made (Wolfe and Crotts, 2011). These models are designed from the producer's (firm's) perspective to provide valuable information on consumer and market responses to the marketing functions by analyzing past data so that consumers' responses can be predicted, upon which future marketing functions can better be planned (Tellis and Zufryden, 1995).
The approach which consists in relying on historical sales data to plan future sales is not based on knowledge of consumer's pre-purchase needs and thus may not significantly reveal the consumers' true responses to marketing functions. MMM models have been criticized for being production-oriented rather than customer-oriented (Popovic, 2006). Lauterborn (1990) had earlier suggested that each of the marketing mix variables should be seen from the consumer's perspective. Moller (2006) also criticized the MMM models for regarding customers as passive and not considering customer behavior, thereby de-personifying marketing activities. These criticisms therefore indicate the need for a bottomup approach which uses consumer's pre-purchase responses in modeling the impact of marketing functions on the consumers' acceptability of a product. The consumer's acceptability of a product is generally reflected in the consumer's increased frequency of purchase and consumption thereof (Tomlins et al., 2007) which ultimately leads to increased market demand and sales.

This study was guided by the conceptual framework shown in Fig. 1. This framework is based on Myers and Allan (1981) who indicate that marketing functions (such as adverts, sales promotion, price and quantity discounts, branding, labeling, packaging, warranty, convenience, etc) influence the consumer's acceptability

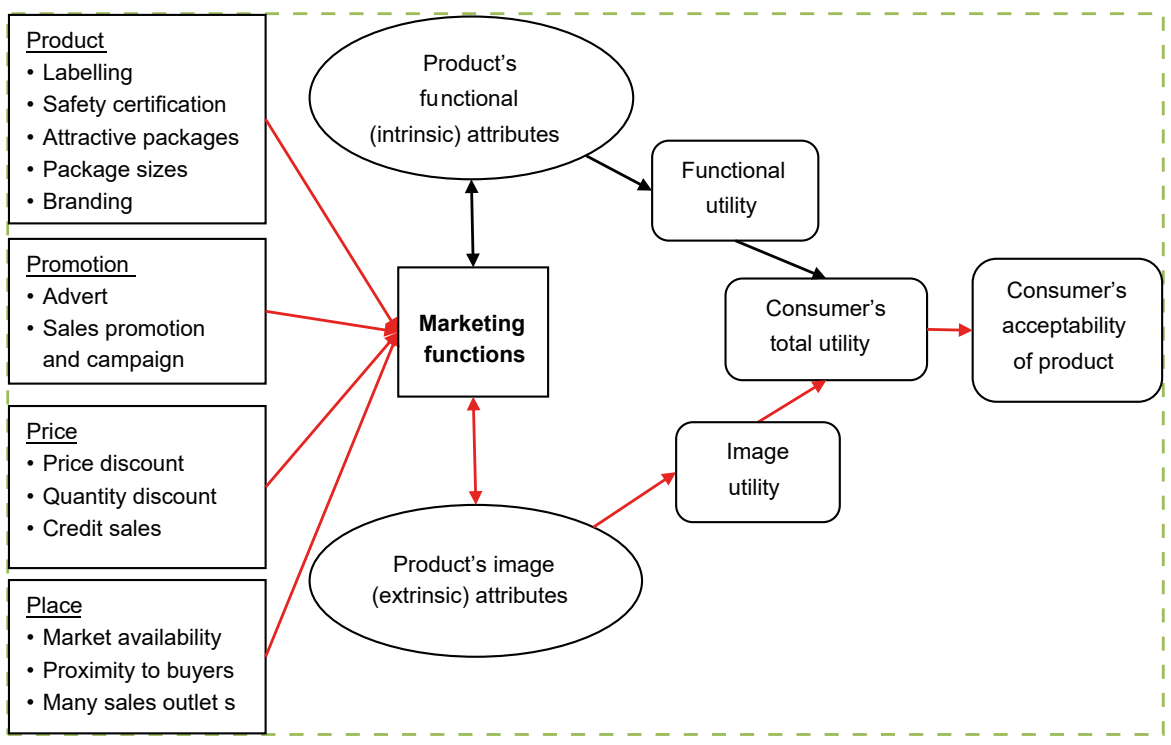

Fig. 1. Conceptual framework of marketing functions influencing the consumer's acceptability of a product

Source: own elaboration. 
because they enhance the consumer's perception of the benefits (utility) derivable from the product's attributes. According to this framework (Fig. 1), every product possesses both functional and image quality attributes (Hogg et al., 2000; Michaut et al., 2002). Functional attributes are intrinsic or inherent and provide functional meanings for the product (Allen et al., 2002) because they possess observable characteristics that offer benefits (functional utility) to consumers (Addis and Holbrook, 2002). The consumer's perception of these functional attributes could be influenced (indirectly) by the functions of marketers (Blijlevens et al., 2009). On the other hand, image attributes are external to the product because they provide symbolic meanings (Meenaghan, 1995) that are related to the product's visual and promotional aspects (Eckman and Wagner, 1994). Marketers often and directly create these image attributes by offering various types of marketing functions (Blijlevens et al., 2009) to provide the consumer with image utility. Marketing functions therefore influence both the functional and image utilities to determine the consumer's total utility which in turn determines the consumer's acceptability of a product (Fig. 1).

Since utility is measured with error, the consumer's acceptability of a product brand, which obviously is a choice, can be modeled probabilistically rather than in a deterministic framework (Swait et al., 1993). The choice model was used to provide some insights into the transformation between a consumer's utility of a product and acceptability on a given occasion (Kamakura and Russell, 1993). Therefore, modeling the households' acceptability of rice brands is considered under the general framework of consumer theory (Lancaster, 1966), which suggests that consumers derive utility from the product's embedded attributes rather than from the product itself. This study follows evidence from literature that households accept a product based on the utilities derivable from its functional and image attributes (Gilaninia et al., 2013; Sethuraman and Tellis, 1991; Simpson et al., 1998). However, some studies such as Eckman and Wagner (1994), Meenaghan (1995), and Michaut et al. (2002), have found that consumers are more likely to be influenced by image attributes than by functional attributes of the product. For this study, functional utility is therefore assumed to be constant. Also, the individual household is assumed to be faced with two sets of alternative rice brands (local or imported) in a choice situation and is supposed to accept (frequently choose) the alternative brand associated with higher image utility (Michaut et al., 2002). Thus, $i^{\text {th }}$ household acceptance $\left(A C C_{i}\right)$ of $j^{\text {th }}$ rice brand is a function of image utility $M U_{i j}$ being derived:

$$
A C C_{i}=f\left(M U_{j}\right)
$$

If $M U_{j}$ and $M U_{k}$ denote the image utility $i^{\text {th }}$ consumer household derives from a set of marketing functions $(Z)$ being offered by the millers and marketers of local and imported rice brands $j$ and $k$ respectively, and if local rice is associated with higher image utility, then $M U_{j}>$ $M U_{k}$. If $A C C_{i j}$ denotes the $i^{\text {th }}$ consumer household's acceptance of local rice brand $j$, then:

$$
\begin{gathered}
A C C_{i j}=M U_{i j}>M U_{i k}=M U_{i j}-M U_{i k}> \\
\varepsilon_{i k}-\varepsilon_{i j}=M U_{i j}>\varepsilon_{i j} \\
\text { for all } j \neq k
\end{gathered}
$$

\section{EXPLANATORY VARIABLES USED IN THE MODEL}

The explanatory variables hypothesized to explain the consumer households' response to the marketing functions of local rice millers and marketers were identified based on the theory and on past empirical work on the marketing mix model. The explanatory variables were classified into two functions (price and marketing). The definitions of the variables used in the analysis are presented in Table 1.

\section{METHODOLOGY}

\section{Study area and method of data collection}

This study was conducted in the Federal Capital Territory (FCT) located in North Central Nigeria. It is located at latitudes between $7^{\circ} 25^{\prime}$ and $9^{\circ} 25^{\prime} \mathrm{N}$ and longitudes between $5^{\circ} 45^{\prime}$ and $7^{\circ} 39^{\prime} \mathrm{E}$, in the savannah vegetation, at the center of the country, with a landmass of 7,315 $\mathrm{km}^{2}$. FCT is characterized by alternating dry and wet seasons with a mean annual rainfall that varies from 1100 to $1600 \mathrm{~mm}$ and temperatures ranging from $12^{\circ} \mathrm{C}$ to $33^{\circ} \mathrm{C}$. The FCT has six area councils, namely Abuja Municipal Area Council (AMAC), Bwari, Gwagwalada, Kwali, Kuje and Abaji. AMAC is the area council where the seat of federal government, its agencies and diplomatic offices are located. It demonstrates the highest infrastructural development levels and is residence to politicians, wealthy Nigerians and diplomats. The 
Obih, U., Baiyegunhi, L. (2018). Consumers' acceptability of local rice brands in Nigeria. Which marketing functions really matter? J. Agribus. Rural Dev., 2(48), 183-196. http://dx.doi.org/10.17306/J.JARD.2018.00412

Table 1. Definitions and measure of variables of this study

\begin{tabular}{|c|c|c|}
\hline Variable & Description & $\begin{array}{l}\text { Expected } \\
\text { sign }^{*}\end{array}$ \\
\hline \multicolumn{3}{|l|}{ Dependent variable } \\
\hline acceptability (ACC) & $\begin{array}{l}\text { Has the frequency of your purchase of local rice increased in the last two years? } \\
\text { Yes }=1 ; 0 \text { if otherwise }\end{array}$ & \\
\hline \multicolumn{3}{|l|}{ Explanatory variables } \\
\hline price & What is the retail price (in naira) of a $50 \mathrm{~kg}$ bag of local rice? & + \\
\hline \multicolumn{3}{|l|}{ Marketing functions } \\
\hline \multicolumn{3}{|l|}{ Product } \\
\hline labeling & Do local rice brands have informative labels? Yes $=1 ; 0$ if otherwise & $+/-$ \\
\hline NAFDAC $^{* *}$ certification & Does NAFDAC certification matter? Yes $=1 ; 0$ if otherwise & $+/-$ \\
\hline attractive packages & Are the packages attractive? Yes $=1 ; 0$ if otherwise & $+/-$ \\
\hline package sizes & Are there many package sizes for local rice brands? Yes $=1 ; 0$ if otherwise & $+/-$ \\
\hline \multicolumn{3}{|l|}{ Promotion } \\
\hline advert & $\begin{array}{l}\text { Are the mass media main information sources about local rice brands? Yes = } 1 \text {; } \\
0 \text { if otherwise }\end{array}$ & $+/-$ \\
\hline sales promotion & Are sales promotions being offered for local rice brands? Yes $=1 ; 0$ if otherwise & $+/-$ \\
\hline \multicolumn{3}{|l|}{ Price } \\
\hline price discount & Are price discounts being offered? Yes $=1 ; 0$ if otherwise & $+/-$ \\
\hline quantity discount & Are quantity discounts being offered? Yes $=1 ; 0$ if otherwise & $+/-$ \\
\hline credit sales & Are credit sales being offered? Yes $=1 ; 0$ if otherwise & $+/-$ \\
\hline \multicolumn{3}{|l|}{ Place } \\
\hline ready availability of product & Are local rice brands readily available in market? Yes $=1 ; 0$ if otherwise & $+/-$ \\
\hline proximity of product & $\begin{array}{l}\text { Are local rice brands found in shops near the consumer's residence? Yes = } 1 \text {; } \\
0 \text { if otherwise }\end{array}$ & $+/-$ \\
\hline sales outlet & Are there many sales outlets for local rice brands? Yes $=1 ; 0$ if otherwise & $+/-$ \\
\hline
\end{tabular}

${ }^{*}$ Based on a priori expectations.

** The National Agency for Food, Drug Administration and Control (NAFDAC) is an agency of the Federal Government responsible for food and drug safety certification and quality control in Nigeria.

Source: own elaboration.

other area councils are satellite towns with poorer infrastructural development and are home mostly to civil servants, farmers, artisans and traders. The choice of FCT for this study is purposive because it is inhabited by multi-class consumers with different socioeconomic characteristics who have varying demand strength and consumption behaviors. Virtually all imported and local rice brands can be found in the major markets in these area councils.
FCT has a total population of about 3.5 million (NPC, 2013) out of which at least 70\% (2.45 million) are rice consumers who constitute the target population of about 490,000 households (based on average of 5 people per household). According to the method used by Yamane (1967), this household population gives a sample size of 400 households which is considered adequate for the interview and data collection. To cover a wider geographical area of the FCT-Abuja, 


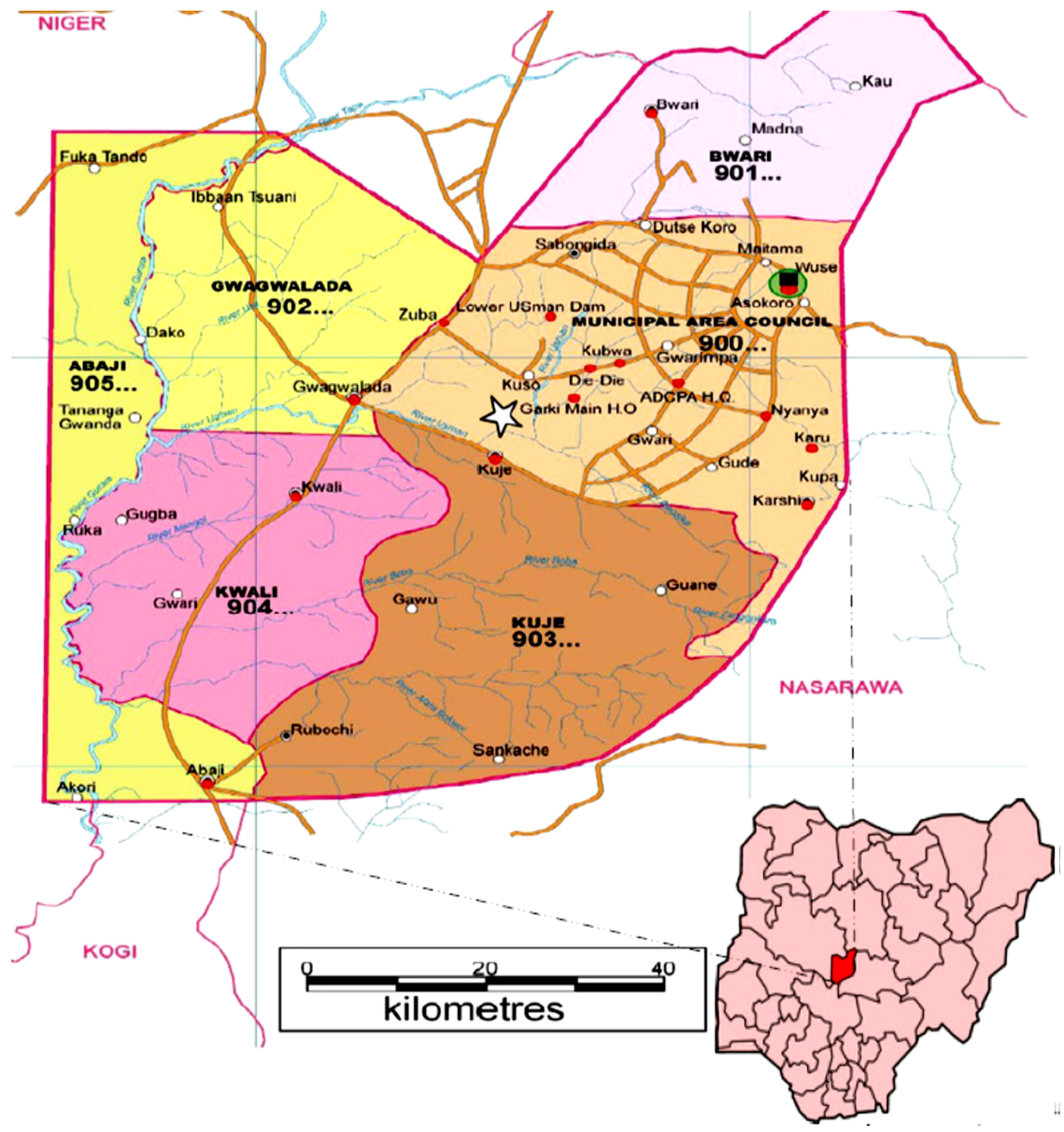

Fig. 2. Map of Nigeria showing the FCT and the six area councils surveyed Source: AGIS, 2014. 
a multi-stage random sampling method was used in selecting a total of 460 respondent households as follows: AMAC (76) ${ }^{2}$, Kuje (77), Gwagwalada (77), Abaji (77), Kwali (76) and Bwari (77). Sampling frames were obtained from the Federal Capital Development Authority (FCDA) and Abuja Geographical Information System (AGIS). Given the presence of multi-class consumers, availability of all imported and local rice brands in the major markets, and adequate sample size, 400 households in the six area councils could adequately represent the national population.

Data was collected using a structured and validated questionnaire. The Jury's method was used to validate the test questionnaire content, while the test-retest method was used to evaluate the questionnaire's reliability. The questionnaire was primarily administered to the household heads during a face-to-face interview. Other household members contributed in providing answers to the questions raised during the interviews. Data was collected on the consumer households' socioeconomic characteristics and acceptability of local rice brands, and the consumers' responses to the marketing functions of millers and marketers of Nigerian local rice brands.

\section{Empirical model for the study}

The Consumer households' acceptability of food products can be estimated within the binary logit framework (Pambo et al., 2016). In this study, a binary logit model was used to analyze the effect of marketing functions on the households' acceptability of local rice brands in Nigeria. The model has been commonly applied to analyze discrete choice data. It is suitable for this study as it allows to analyze whether there has been increase in the frequency of the household's purchase of local rice brands. Hence, this study specifies a binary logit model (discrete choice method) as the statistical model of probability that the $i^{\text {th }}$ consumer household accepts local rice brand $j \operatorname{Pr}\left(A C C_{i j}=1\right)$ because it possesses higher image utility $M U_{i j}$ and can be expressed in terms of the logistic distribution (McFadden, 1974) as follows:

$$
\operatorname{Pr}\left(A C C_{i j}=1\right)=\frac{\exp ^{M U_{i j}}}{1+\exp ^{M U_{i j}}}
$$

where $M U_{i j}=\beta_{0}+\beta_{j} Z_{i}+\varepsilon_{i}$

\footnotetext{
${ }^{2}$ Values in parenthesis denote the number of households interviewed in the area council surveyed.
}

$Z_{i}$ represents a vector of explanatory variables (including price and marketing functions of millers and marketers of local rice brands) influencing the $i^{\text {th }}$ household's decision to consume local rice brands more frequently; $\beta_{j}$ is a vector of estimated coefficients; and $\varepsilon_{i}$ is the error term. $A C C_{i j}$ is the dependent variable representing the rice brand chosen by a household and takes the value of 1 if the household's frequency of consumption of local rice brand has increased or 0 otherwise. The increased frequency of the household's consumption of local rice brands is used as a reference. According to Latvala (2010), the decision rule is as follows: if $\operatorname{Pr}\left(A C C_{i j}=1\right)>0.5$, there is consumers' acceptability of local rice brands, which is not true if $\operatorname{Pr}\left(A C C_{i j}=1\right) \leq 0.5$.

The results of the binary logit model are interpreted in terms of the odds ratios, i.e. the ratios of the probability of choosing one outcome category over the reference category. These ratios are defined as:

$$
I_{n}\left[\frac{\operatorname{Pr}\left(A C C_{i j}\right)}{\operatorname{Pr}\left(A C C_{i k}\right)}\right]=Z_{i}\left(\beta_{j}-\beta_{k}\right)=Z_{i} \beta_{j} \text { if } k=1
$$

A positive parameter indicates that the probability of a household's acceptability of local rice brands over the imported rice brands increases compared to the probability of a household's acceptability of imported rice brands over the local rice brands.

\section{RESULTS AND DISCUSSION}

\section{Households' socioeconomic characteristics}

The socio-economic characteristics of the respondents are presented in Table 2. 65\% of the sample household heads are women; most of them (93\%) are married while $7 \%$ are single. The average age of household heads is 47 , and the average time spent in formal schooling is 16 years, indicating that household heads are educated. The average household size is 5 , with most household heads receiving an average monthly income of NGN 88,350 (about USD 441). This means that the households live on an average of about USD 10 per day, which is well above the national monthly minimum wage of NGN 18,000 (about USD 90). Approximately $51 \%$ of the consumer households agreed that their frequency of purchasing local rice brands has increased in the last two years, while about $49 \%$ of the households have not. 
Obih, U., Baiyegunhi, L. (2018). Consumers' acceptability of local rice brands in Nigeria. Which marketing functions really matter? J. Agribus. Rural Dev., 2(48), 183-196. http://dx.doi.org/10.17306/J.JARD.2018.00412

Table 2. Socio-economic characteristics of households in the survey

\begin{tabular}{|c|c|c|c|c|}
\hline Characteristics & Category & No. of respondents & Percentage & Mean \\
\hline \multirow[t]{2}{*}{ Gender } & male & 163 & 35.4 & $\mathrm{~N} / \mathrm{A}$ \\
\hline & female & 297 & 64.6 & \\
\hline \multirow[t]{4}{*}{ Age (years) } & $25-35$ & 20 & 4.30 & 47.27 \\
\hline & $36-46$ & 72 & 15.4 & \\
\hline & $47-57$ & 223 & 48.5 & \\
\hline & $58-68$ & 145 & 31.5 & \\
\hline \multirow{4}{*}{$\begin{array}{l}\text { Education level } \\
\text { (number of years spent } \\
\text { in formal schooling) }\end{array}$} & 1-6 primary & 74 & 16.2 & 15.78 \\
\hline & $7-12$ secondary & 82 & 17.8 & \\
\hline & $13-18$ tertiary & 267 & 58.0 & \\
\hline & 19-24 post-graduate & 37 & 8.00 & \\
\hline \multirow[t]{3}{*}{ Marital status } & single & 31 & 6.70 & - \\
\hline & married & 427 & 92.80 & \\
\hline & divorced & 2 & 0.50 & \\
\hline \multirow{3}{*}{$\begin{array}{l}\text { Household size (number } \\
\text { of persons) }\end{array}$} & $2-4$ & 119 & 25.90 & 4.87 \\
\hline & $5-7$ & 268 & 58.30 & \\
\hline & $8-10$ & 73 & 15.80 & \\
\hline \multirow{4}{*}{$\begin{array}{l}\text { Household's monthly } \\
\text { income (NGN thousand) }\end{array}$} & $20-120$ & 260 & 56.5 & NGN 88,350 \\
\hline & $121-221$ & 128 & 27.8 & \\
\hline & $222-322$ & 54 & 11.7 & \\
\hline & $323-423$ & 18 & 3.9 & \\
\hline \multirow{2}{*}{$\begin{array}{l}\text { Acceptability of local } \\
\text { rice? }\end{array}$} & yes & 233 & 51 & - \\
\hline & no & 227 & 49 & \\
\hline
\end{tabular}

Source: field survey data, 2014.

Distribution of households according to their responses to marketing functions of local rice millers and marketers

The distribution of households by responses to the marketing functions of millers and marketers of local rice brands is presented in Table 3 . There are wide gaps between the percentages of households with affirmative and non-affirmative responses. For instance, in AMAC, only $7 \%$ of the households affirmed that local rice brands have informative labels on their packages, while $93 \%$ of the households could not affirm if such service is being provided. In all the marketing functions investigated, the households' affirmative and non-affirmative responses follow a similar pattern.

The above descriptive analysis shows that, with the observed patterns in the data, there is a consensus among the consumer households that marketing functions are not adequately provided by the millers and marketers of local rice brands in Nigeria. Given the evidence in literature that marketing functions impact consumer behavior, demand and sales of food products (Sethuraman and Tellis, 1991), it implies there is opportunity for shifting the current consumption preference away from imported rice brands to local rice brands if 
Obih, U., Baiyegunhi, L. (2018). Consumers' acceptability of local rice brands in Nigeria. Which marketing functions really matter? J. Agribus. Rural Dev., 2(48), 183-196. http://dx.doi.org/10.17306/J.JARD.2018.00412

Table 3. Percentage distribution of the households' responses to marketing functions of local rice millers and marketers

\begin{tabular}{|c|c|c|c|c|c|c|c|}
\hline \multirow{2}{*}{$\begin{array}{l}\text { Marketing functions } \\
\text { provided by local rice } \\
\text { millers and marketers }\end{array}$} & \multirow{2}{*}{ Pooled } & \multicolumn{6}{|c|}{ Households' locations and responses } \\
\hline & & AMAC & Abaji & Kwali & Gwagwalada & Kuje & Bwari \\
\hline Labeling & $6(94)$ & $7(93)$ & $6(94)$ & $6(94)$ & $6(94)$ & $5(95)$ & $4(96)$ \\
\hline NAFDAC certification & $15(85)$ & $17(83)$ & $16(84)$ & $15(85)$ & $15(85)$ & $16(84)$ & $15(85)$ \\
\hline Attractive package & $15(85)$ & $12(88)$ & $18(82)$ & $17(83)$ & $13(87)$ & $14(86)$ & $18(82)$ \\
\hline Package sizes & $27(73)$ & $34(66)$ & $27(73)$ & $21(79)$ & $25(75)$ & $30(70)$ & $27(73)$ \\
\hline Advertisement & $14(86)$ & $10(90)$ & $15(85)$ & $10(90)$ & $16(84)$ & $11(89)$ & $19(81)$ \\
\hline Sales promotion & $19(81)$ & $13(87)$ & $16(84)$ & $23(77)$ & $26(74)$ & $16(84)$ & $19(81)$ \\
\hline Price discount & $6(94)$ & $2(98)$ & $4(96)$ & $10(90)$ & $8(92)$ & $3(97)$ & $9(91)$ \\
\hline Quantity discount & $9(91)$ & $5(95)$ & $8(92)$ & $9(91)$ & $10(90)$ & $8(92)$ & $12(88)$ \\
\hline Credit sales & $6(94)$ & $7(93)$ & $5(95)$ & $8(92)$ & $6(94)$ & $3(97)$ & $5(95)$ \\
\hline Market availability & $18(82)$ & $4(96)$ & $26(74)$ & $13(87)$ & $40(60)$ & $5(95)$ & $23(77)$ \\
\hline Proximity & $23(77)$ & $5(95)$ & $39(61)$ & $12(88)$ & $34(66)$ & $9(91)$ & $40(60)$ \\
\hline Sales outlet & $16(84)$ & $18(82)$ & $22(78)$ & $18(82)$ & $17(83)$ & $12(88)$ & $8(92)$ \\
\hline
\end{tabular}

Values in parenthesis are percentages of households with non-affirmative responses to the questions on marketing functions of local rice millers and marketers.

Source: field survey data, 2014.

adequate marketing functions are properly integrated into Nigeria's rice development policies and programs.

\section{Estimation of marketing functions influencing the consumer households' acceptability of local rice brands}

A binary logistic regression model for marketing functions influencing the consumer's acceptability of local rice brands was estimated using SPSS version 20.0. The results are presented in Table 4 . The estimated binary model gave higher correct predictions of acceptability of local rice brands by $62 \%$ of the households. In the estimated model, the Nagelkerke's $R^{2}$ is 0.125 , the Hosmer and Lemeshow (H-L) tests show significance values greater than 0.05 , while the Chi-square tests of 2 Log Likelihood are significant at $1 \%$. These indicate there is no significant difference between observed and model-predicted values, implying a moderately strong relationship between the predictors and the prediction. Therefore, the estimated binary model provides quite a good fit and a strong explanatory power. The variance inflation factor (VIF) for all the explanatory variables is less than 10 indicating absence of multicollinearity in the estimated model (Menard, 1995).

The coefficients of parameter estimates of the binary logit model only provide the direction of the effect of the independent variables on the dependent (response) variable (Table 4) and do not represent the actual magnitude of change or probabilities. Therefore, the marginal effects from the binary model, which measures the expected change in probability of a choice being made with respect to a unit change in the independent variable, are reported as the $\exp (\beta)$ in Table 4 . The estimated coefficients for the household's acceptability of local rice brands are compared with non-acceptability of local rice brands as the base reference choice.

The estimated coefficient for the price of local rice brands is positive and statistically significant for the probability of household acceptability of local rice brands (Table 4). This implies that an increase in the prices of local rice brands is likely to increase the probability of the household's acceptability of local rice brands. The marginal effect suggests that the likelihood for such household's choice of acceptance over 
Obih, U., Baiyegunhi, L. (2018). Consumers' acceptability of local rice brands in Nigeria. Which marketing functions really matter? J. Agribus. Rural Dev., 2(48), 183-196. http://dx.doi.org/10.17306/J.JARD.2018.00412

Table 4. Parameter estimates of the binary logit model explaining the effect of marketing functions on the households' acceptability of local rice brands

\begin{tabular}{|c|c|c|}
\hline \multirow{2}{*}{ Variables } & \multicolumn{2}{|c|}{ Acceptability of local rice brands } \\
\hline & $\beta$ & $\operatorname{Exp}(\beta)$ \\
\hline Price & $0.0003(0.0002)^{* * *}$ & 0.998 \\
\hline Labeling & $-0.482(0.432)$ & 0.617 \\
\hline NAFDAC certification & $0.612(0.293)^{* *}$ & 1.844 \\
\hline Attractive packaging & $0.367(0.306)$ & 1.443 \\
\hline Package size & $-0.194(0.223)$ & 0.823 \\
\hline Advertisement & $-0.933(0.366)^{* *}$ & 0.393 \\
\hline Sales promotion & $0.857(0.311)^{* * *}$ & 2.357 \\
\hline Price discount & $0.061(0.496)$ & 1.062 \\
\hline Quantity discount & $-0.464(0.441)$ & 0.629 \\
\hline Credit sales & $-0.063(0.461)$ & 0.939 \\
\hline Ready availability of product & $0.823(0.266)^{* * *}$ & 2.277 \\
\hline Proximity of product to consumers & $-0.490(0.249)^{* *}$ & 0.613 \\
\hline Sales outlets & $0.741(0.295)^{* *}$ & 2.098 \\
\hline Constant & $2.407(1.397)^{*}$ & 11.097 \\
\hline No. of observations & 460 & \\
\hline-2 Log Likelihood & 592. & \\
\hline Nagelkerke $\mathrm{R}^{2}$ & & \\
\hline H-L Test & 0.3 & \\
\hline VIF & & \\
\hline Correctly predicted & $62 \%$ & \\
\hline
\end{tabular}

Note: Values in parenthesis are standard errors. *** Denotes statistically significant at the $1 \%$ probability level. ${ }^{* *}$ Denotes statistically significant at the $5 \%$ probability level. *Denotes statistically significant at the $10 \%$ probability level.

Source: Computed from field survey data, 2014.

rejection of the local rice brands increases by $99 \%$ (Table 4). A plausible explanation could be that consumers perceive higher prices as an indication of improvements in the quality attributes of local rice brands. Higher prices of local rice coupled with improvement in quality attributes will likely increase the demand and consumption of local rice, provided the prices of imported rice brands remain higher.

The estimated coefficient for the NAFDAC certification of local rice brands is positive and statistically significant for the probability of household acceptability of local rice brands (Table 4). This implies that local rice brands that have NAFDAC certification are more likely to be accepted by consumer households than those without NAFDAC certification. The marginal effect suggests that the likelihood for such household's choice of acceptance over rejection of the local rice brands increases by $84 \%$ (Table 4 ). A possible reason could be that consumers in the area are conscious of food safety and are aware of the importance of NAFDAC certification of food products. In recent years, NAFDAC has stepped up the fight against fake food and drugs especially in major 
markets across Nigeria. This is consistent with the food safety theory; the demand for a food commodity is an increasing function of the consumer's perceived safety of consuming such a commodity (Kim, 2003; Lee et al., 2004).

The estimated coefficient for advertisement in the mass media as a consumer household's major source of information is negative and statistically significant for the probability of household acceptability of local rice brands (Table 4). This implies that the more households accept local rice brands based on the information they obtained, the less likely such information was obtained from the mass media. The marginal effect suggests that the likelihood for a household that depends on mass media as major information source to exhibit acceptance over rejection of local rice brands decreases by $61 \%$ (Table 4). A possible reason may be that households do not receive adequate mass media advertisement on local rice brands because millers and marketers incurred higher relative costs per unit time of airing such adverts, hence other means of communication such as word-of-mouth and retailers' information are being exploited by consumers in getting information. These alternative information sources may be ineffective perhaps due to their lower demographic coverage. Besides, mass media advertisement provides consumers with some image utility. This is consistent with Ramasamy et al. (2005) who found that commercial advertisements were the most important source of information, followed by displays in retail outlets.

The estimated coefficient for sales promotions is positive and statistically significant for the probability of household acceptability of local rice brands (Table 4). This implies that an increase in sales promotions of local rice brands is likely to increase the probability of the household's acceptability of local rice brands. The marginal effect suggests that the likelihood for such household's choice of acceptance over rejection of the local rice brands increases by $135 \%$ (Table 4 ). A plausible explanation could be that sales promotions provide the consumer households with an opportunity to purchase, know more and appreciate the improvements in the functional qualities of local rice brands over the imported ones. Frequent sales promotions are likely to afford consumers the opportunity to try new local rice brands, thereby enhancing the likelihood of increasing the purchase of local rice brands.
The estimated coefficient for "ready market availability of local rice brand" is positive and statistically significant for the probability of household acceptability of local rice brands (Table 4). This implies that an increase in the market availability of local rice brands is likely to increase the probability of the household's acceptability of local rice brands. The marginal effect suggests that the likelihood for such household's choice of acceptance over rejection of the local rice brands increases by $127 \%$ (Table 4). A possible reason could be that, in a highly competitive market situation, consumers are more likely to purchase those products that are readily and always available in the market. This agrees with the findings of Azabagaoglu and Gaytancioglu (2009), and is consistent with Say's law, which states that supply creates its own demand.

The estimated coefficient for product proximity is negative and statistically significant for the probability of household acceptability of local rice brands (Table 4). This implies that the more households accept local rice brands, the less likely such local rice was bought from shops nearest to the consumers' residence. The marginal effect suggests that the likelihood for a household that buys local rice from a nearby shop to exhibit acceptance over rejection of local rice brands decreases by $39 \%$ (Table 4 ). A possible reason may be that most households believe that foodstuffs are cheaper and often prefer and buy their foodstuffs, including rice, in major markets instead of nearby corner shops in residential areas. This is consistent with the traditional foodstuff purchasing behaviors of most households in Nigeria.

The estimated coefficient for sales outlets of local rice brands is positive and statistically significant for the probability of household acceptability of local rice brands (Table 4). This implies that an increase in the number of sales outlets of local rice brands is likely to increase the probability of the household's acceptability of local rice brands. The marginal effect suggests that the likelihood for such household's choice of acceptance over rejection of the local rice brands increases by $109 \%$ (Table 4). The reason could be that, in a highly competitive market situation, consumer households are more likely to buy rice brands that have a higher number of sales outlets because such brands are likely to be readily available in the market. Besides, a large number of sales outlets may reflect the efficiency of the rice brand's marketing system. 
Obih, U., Baiyegunhi, L. (2018). Consumers' acceptability of local rice brands in Nigeria. Which marketing functions really matter? J. Agribus. Rural Dev., 2(48), 183-196. http://dx.doi.org/10.17306/J.JARD.2018.00412

Table 5. Probabilities of the household's acceptability of local rice brands across locations

\begin{tabular}{|c|c|c|c|c|c|c|c|c|}
\hline \multirow{2}{*}{$\begin{array}{l}\text { Household } \\
\text { behavior }\end{array}$} & \multirow{2}{*}{$\begin{array}{c}\text { Probabilities of } \\
\text { acceptance }\end{array}$} & \multicolumn{6}{|c|}{ Location (Area Council) } & \multirow{2}{*}{$\operatorname{Pr}_{\text {ACCpooled }}$} \\
\hline & & AMAC & Abaji & Kwali & Gwagwalada & Kuje & Bwari & \\
\hline \multirow{3}{*}{$\begin{array}{l}\text { Acceptability } \\
\text { of local rice }\end{array}$} & $\operatorname{Pr}_{\text {ACCmean }}(\mathrm{Y}=1)<0.5$ & 0.379 & 0.382 & 0.395 & 0.372 & 0.361 & 0.373 & 0.377 \\
\hline & $\operatorname{Pr}_{\text {ACCmean }}(Y=1)>0.5$ & 0.621 & 0.618 & 0.605 & 0.628 & 0.609 & 0.627 & 0.623 \\
\hline & $\operatorname{Pr}_{\text {ACCPooledmean }}(\mathrm{Y}=1)$ & 0.569 & 0.589 & 0.622 & 0.627 & 0.577 & 0.563 & 0.591 \\
\hline
\end{tabular}

Note:

$\operatorname{Pr}_{\text {ACCmean }}(\mathrm{Y}=1)$ is the mean probability of the household's acceptability of local rice brands.

$\operatorname{Pr}_{\text {pooledmean }}(Y=1)$ is the pooled mean probability of the household's acceptability of local rice across the six locations.

Source: computed from field survey data, 2014.

\section{Consumer household's acceptability of local rice brands}

In this study, an attempt was made to determine the consumers' acceptability of local rice brands by estimating the probability that a household's frequency of purchasing local rice brands has increased in the last two years due to the marketing functions of local rice millers and marketers, as presented in Table 5. Following Latvala (2010), the mean probability of the household's acceptability of local rice brands across the six locations $\left(\operatorname{Pr}_{\text {ACCPooledmean }}\right)$, calculated to be 0.591 , confirms that there is a general acceptability of local rice brands among rice consuming households in Nigeria. This is consistent with the results obtained from similar studies in other countries where import substitution is being applied as an economic development strategy (Doo Bong et al., 2012; Kim, 2003; Lee et al., 2004).

\section{CONCLUSION AND IMPLICATIONS FOR THE RICE MARKETING POLICY}

The consumer households' data shows that marketing functions of local rice millers and marketers are inadequate. However, this provides marketing managers with opportunities for increasing the household's acceptability and consumption of local rice brands. Data from the results of the household's pre-purchase responses show that the local rice industry in Nigeria needs more improvements in marketing functions that enhance the promotion and distribution of local rice brands than in those focused on pricing and product enhancements. This is an indication that local rice brands are beginning to gain consumers' acceptance and can compete favorably with imported rice brands both in price and quality.

Given the above-average literacy and income levels of people living in the FCT, there is high likelihood of consumers accepting local rice brands if adequate promotional campaigns are developed. Therefore, it is imperative for marketing managers to specifically direct their efforts in designing and implementing campaign programs to promote the functional and image attributes of local rice brands such as good physiochemical properties, informative labeling and NAFDAC certification which are yet to be fully employed in the light of findings from recent studies. This needs to be supported by an efficient distribution system that ensures the availability of local rice brands in major markets and sales outlets across Nigeria.

\section{ACKNOWLEDGEMENTS}

We are grateful to Dr. Olateju Omole of M\&E Department and the extension agents of FCT Agricultural Development Project (ADP) for their assistance during the data collection and organization stages.

\section{REFERENCES}

Addis, M., Holbrook, M. S. (2002). On the Conceptual link between mass customisation and experiential consumption: An explosion of subjectivity. J. Cons. Beh., 1(1), 50-66.

Adeyeye, J. A., Navesero, E. P., Ariyo, O. J., Adeyeye, S. A. (2010). Consumer preference for rice consumption in Nigeria. J. Human. Soc. Sci. Creat. Arts, 5(1), 26-36.

AGIS (2014). AGIS deploys high resolution satellite imagery of the FCT, Abuja Geographic Information System. Retrieved from http://agis.fcta.gov.ng/ 
Allen, M. M., Ng, S. H., Wilson, M. (2002). A functional approach to instrumental and terminal values and the value-attitude-behaviour system of consumer choice. Eur. J. Market., 36(1/2), 111-135.

Azabagaoglu, M. O., Gaytancioglu, O. (2009). Analyzing consumer preference to different rice varieties in Turkey. Agric. Tropic. Subtropic., 42(3), 118-125.

Bamidele, F. S., Abayomi, O. O., Esther, O. A. (2010). Economic analysis of rice consumption patterns in Nigeria. $\mathrm{J}$. Agric. Sci. Technol., 2(12), 1-11.

Basorun, J. O. (2009). Analysis of the relationships of factors affecting rice consumption in a targeted region in Ekiti State, Nigeria. J. Appl. Quant. Methods, 4(2), 2-15.

Blijlevens, J., Creusen, M. E. H., Schoormans, J. P. L. (2009). How consumers perceive product appearance: The identification of three product appearance attributes. Int. J. Design, 3(3), 27-35.

Campbell, R., Schiff, H., Snodgrass, D., Neven, D., Downing, J. Sturza, D. (2009). Global food security response: West Africa rice value chain analysis. USAID microREPORT \# 161. Washington, DC.

CARD (2015). Private sector investment in the rice sector in response to government policies in Nigeria presentation at the sixth general meeting of the coalition for African rice development (CARD) November 18-19, 2015 Accra, Ghana. Available at: https://riceforafrica.net/images/stories/PDF/S2-2EN.pdf Accessed 5/12/2016

Doo Bong, H., Rodolfo, M. N., Ji Yong, L., Jong, M. Y. (2012). Assessing Korean Consumers' valuation for domestic and imported rice: Importance of country of origin and food miles information. Paper presented at the annual meeting of Southern Agricultural Economics Association, Birmingham, AL, February 4-7, 2012.

Eckman, M., Warner, J. (1994). Judging the attractiveness of product design: The effect of visual attributes and consumer characteristics. Adv. Consum. Res., 21(1), 560-564.

Erenstein, O., Lançon, F., Osiname, O., Kebbeh, M. (2004). Operationalising the strategic framework for rice sector revitalisation in Nigeria. Project report - The Nigerian rice economy in a competitive world: Constraints, opportunities and strategic choices. Retrieved from http://pdf.usaid. gov/pdf docs/Pdacd181.pdf

Gilaninia, S., Taleghani, M., Azizi, N. (2013). Marketing mix and consumer behaviour. Arab. J. Bus. Manag. Rev., 2(12), 53-58.

Grönroos, C. (1994). From marketing mix to relationship marketing: Towards a paradigm shift in marketing. Manag. Dec., 32(2), 4-20.

Gyimah-Brempong, K., Dorosh, P., Kuku, O., Pradesha, A., Ajibola, A. (2012). Informing Nigeria's agricultural transformation agenda with policy analysis and research evidence. Paper presented at NSSP national conference held in Abuja, Nigeria, November 13-14, 2012.

Hogg, M. K., Cox, A. J., Keeling, K. (2000). The impact of self-monitoring on image congruence and product/brand evaluation. Eur. J. Market., 34(5/6), 641-666.

Jairo, M. (2008). Making microeconomic policy work for small business and enterprise development. AfricaGrowth Agenda, 5(1), 7-12.

Johnson, M., Takeshima, H., Gyimah-Brempong, K., KukuShittu, O. (2013). Policy options for accelerated growth and competitiveness of the domestic rice economy in $\mathrm{Ni}$ geria. IFPRI policy note 35, IFPRI Washington, D.C.

Kamakura, W. A., Russell, G. (1993). Measuring brand value with scanner data. International J. Res. Market., 10(1), 9-21.

Kellerman, B. J., Gordon, P. J., Hekmat, F. (1995). Product and pricing courses are under-represented in undergraduate marketing curricula. J. Prod. Brand Manag., 4(1), $18-25$.

Kim, S. S. (2003). A study on consumers' willingness-to-pay for domestic and imported rice. Research report, Korea Food Research Institute.

Kotler, P., Keller, K. L. (2013). Marketing management. Praha: Grada.

Kurtz, D. L., Boone, L. E. (1987). Marketing (3rd ed.). Chicago: The Dryden Press.

Lancaster, K. J. (1966). A new approach to consumer theory. J. Polit. Econ., 74(2), 132-157.

Lancon, F., Olaf, E., Akande, S. O., Titilola, S. O., Akpokodje, G., Ogundele, O. O. (2003). Imported rice retailing and purchasing in Nigeria: A survey. Project report - The Nigerian rice economy in a competitive world: Constraints, opportunities and strategic choices. West Africa rice development association (WARDA) Abidjan, Coted'Ivoire.

Latvala, T. (2010). Risk, information and trust in the food chain: Factors explaining consumer willingness to pay. Int. J. Food Syst. Dyn., 1(4), 295-304.

Lauterborn, B. (1990). New marketing litany: Four Ps passé: C-words take over. Advertising age, 61(41), 26.

Lee, J. H., Seo, J. G., Choi, J. H., Kim, T. G., Jeong, J. G., Kim, S. H., Lim, S. Y. (2004). A study on strategy for 2004 rice negotiation. Research report, Korea rural economic institute.

Martensen, A., Maouritsen, J. (2016). Prioritising marketing activities in different types of marketing functions. Total Qual. Manag. Bus. Excell., 2(1), 1-21.

Mathur, A., Moschis, G. P., Lee, E. (2003). Life events and brand preference changes. J. Cons. Beh., 3(1),129-141.

McCarthy, E. J. (1964). Basic Marketing, IL: Richard D. Irwin. 
McDaniel, S. W., Hise, R. T. (1984). Shaping the Marketing Curriculum: The CEO perspective. J. Marke. Edu., 27-32. Retrieved from: http://journals.sagepub.com/doi/ abs/10.1177/027347538400600207

Meenaghan, T. (1995). The role of advertising in brand image development. J. Prod. Brand Manag., 4(4), 23-34.

Menard, S. (1995). Applied logistic regression analysis. Sage University series on quantitative applications in the social sciences. Thousand Oaks, CA: Sage.

Michaut, A. M. K., van Trijp, H. C. M., Steenkamp, B. E. M. (2002). Dimensions of product newness and their differential effect on market success. Paper presented at $31^{\text {st }}$ EMAC conference, May 28-31, Braga, Portugal.

Möller, K. (2006). The marketing mix revisited: Towards the 21 st century marketing by E. Constantinides. J. Market. Manag., 22(3), 439-450.

Myers, J. H., Allan, D. S. (1981). Research in Marketing. JAI Press Inc.

Nundkumar, P., Singh, A. M. (2016). Repositioning the Durban chamber of commerce using the 4Ps of marketing. Retail Market. Rev., 12(2), 1-13.

Ogbe, A. O., Okoruwa, V. O., Saka, O. J. (2011). Competitiveness of Nigerian rice and maize production ecologies: A policy analysis approach. Tropic. Subtropic. Agroeco., 14, 493-500.

Ogundele, F. (2013). Determinants of household rice consumption in Nigeria: Application of Working-lesser single equation model. Net J. Agric. Sci., 1(2), 48-55.

Ogundele, O. (2014). Factors influencing consumers' preference for local rice in Nigeria. Afr. J. Market. Manag., 6(4), $49-55$.

Pambo, K. O., Julius, J., Okello, J. J., Mbeche, R., John, N., Kinyuru, J. N. (2016). Consumer acceptance of edible insects for non-meat protein in western Kenya. Paper presented at the 5th African Association of Agricultural Economists (AAAE) conference at the United Nations conference center, Addis Ababa-Ethiopia, September 23 26, 2016.

Palmer, A. (2004). Introduction to Marketing - Theory and Practice, UK: Oxford University Press.

Popovic, D. (2006). Modelling the marketing of high-tech start-ups. J. Target. Measur. Anal. Market., 14(3), 260-276.
PROPCOM (2007). Demand and supply study on domestic and imported rice in Kano area. Monograph Series \# 22, July, 2007.

Ramasamy, K., Kalaivanan, G., Sukumar, S. (2005). Consumer behaviour towards instant food products. Int. J. Market., 35(6), 24-25.

Sethuraman, R., Tellis, G. J. (1991). An analysis of the tradeoff between advertising and pricing. J. Market. Res., 31(1), 160-174.

Seck, P. A., Tollens, E., Wopereis, M. C. S., Diagne, A., Bamba, I. (2010). Rising trends and variability of rice prices: threats and opportunities for sub-Saharan Africa. Food Policy, 35(5), 403-411.

Swait, J., Erdem, T., Louviere, J., Dubelaar, C. (1993). The equalization price: A consumer-perceived measure of brand equity. Int. J. Res. Market., 10(1), 23-45.

Tellis, G. J. (1988). The price sensitivity of competitive demand: A meta-analysis of sales response models. J. Market. Res., 15(1), 331-341.

Tellis, G. J., Zufryden, F. (1995). Cracking the retailer's decision problem: Which brand to discount, how much, when and why? Market. Sci., 14(3), 271-299.

Tomlins, K. I., Manful, J. T., Larwer, P., Hammond, L. (2005). Urban consumer preferences and sensory evaluation of locally produced and imported rice in West Africa. Food Qual. Pref., 16(1), 79-89.

Tomlins, K., Manful, J., Gayin, J., Kudjawu, B., Tamakloe, I. (2007). Study of sensory evaluation, consumer acceptability, affordability and market price of rice. J. Sci. Food Agric., 87(8), 1564-1575.

USAID (2009). Global food security response: West Africa rice value chain analysis. MicroReport, No. 161, United States Agency for International Development (USAID), Washington, D.C.

Wolfe, M. J., Crotts, J. C. (2011). Marketing mix modelling for the tourism industry: A best practices approach. Int. J. Tour. Sci., 11(1), 1-15.

Yamane, T. (1967). Statistics: An Introductory Analysis (2 ${ }^{\text {nd }}$ Ed.). New York: Harper and Row. 